Article

\title{
Mapping Urbanization as an Anthropedogenetic Process: A Section through the Times of Urban Soils
}

\author{
Antoine Vialle ${ }^{1, *}$ and Mario Giampieri ${ }^{2}$ \\ ${ }^{1}$ Laboratory of Urbanism, École Polytechnique Fédérale de Lausanne, 1015 Lausanne, Switzerland; \\ E-Mail: antoine.vialle@epfl.ch \\ ${ }^{2}$ MIT Norman B. Leventhal Center for Advanced Urbanism, Massachusetts Institute of Technology, Cambridge, MA 02139, \\ USA; E-Mail: marioag@mit.edu \\ * Corresponding author
}

Submitted: 29 January 2020 | Accepted: 2 June 2020 | Published: 30 June 2020

\begin{abstract}
Current trends of spatial planning policies give a strategic role to soils, the multifunctionality of which must be considered as a crucial driver facing cities' forthcoming social-ecological transition. However, soils within urban areas are insufficiently studied as a long-term record of environmental history and heavy anthropization. This article investigates the extreme qualitative variability of urban soils by presenting a conceptual model and cartographic workflow highlighting soil evolution processes as a value which co-variates with urbanization. Based on a case study in West Lausanne (Switzerland), the layers and map series of an atlas underscore the applicability of different types of information and spatial analysis for documenting the influence of anthrosediments and land cover changes. Combined with empirical profile descriptions, such a consolidated concept map defines a template, in the form of a complex spatio-temporal figure, on which to apply the state factor approach. Instead of using a simple spatial transect or gradient, the increasing anthropic dominance over original landscape conditions is explained using a section through time. An urban anthroposequence consequently retraces contrasting soil development pathways as a coherent bundle of historical trajectories. Such a narrative integrates various facets of land use, including one-off construction techniques and recurring maintenance practices, planning tools, and morphologies, into a specific 'project for the ground' which brought forth the mixed mesh of the Swiss Plateau 'cityterritory.' Ultimately, the dynamic vision conveyed by these intertwined soil-urbanization coevolution trajectories outlines opportunities for the regeneration of the resource deposit made up of both West Lausanne's urban fabric and its soils as a palimpsest.
\end{abstract}

\section{Keywords}

conceptual model of anthropedogenesis; anthrosediments; anthroposequence; ecosystem history; land cover change; soil mapping; spatial planning; urban soils; urban history

Issue

This article is part of the issue "Territories in Time: Mapping Palimpsest Horizons" edited by Chiara Cavalieri (UCLouvain, Belgium) and Elena Cogato Lanza (EPFL, Switzerland).

(C) 2020 by the authors; licensee Cogitatio (Lisbon, Portugal). This article is licensed under a Creative Commons Attribution 4.0 International License (CC BY).

Soil landscapes and their spatial variation are exciting and complex. But to understand soils fully, they must be studied in space and time. Indeed, we embrace Daniels and Hammer's (1992) statement that soils are four-dimensional systems, not simply the onedimensional profile. (Schaetzl \& Thompson, 2015)

\section{Introduction: Documenting and Projecting Urban Soils as a Long-Term Record of Environmental History and Heavy Anthropization}

Motivated by ever-increasing soil degradation due to past and present urban growth dynamics (Gardi, 2017), the current trend of spatial planning policies at the Swiss 
and European levels is to promote increased soil protection (European Commission, 2016; Swiss Spatial Planning Act, 2019). These policies aim to avoid new developments on agricultural and natural land, and to reorient urban growth towards existing urban areas which must be restructured and densified. Such an objective, formulated as "inward urbanization" (Häberli, Lüscher, Praplan Chastonay, \& Wyss, 1991), shifts the emphasis onto soils situated within urban areas, which are cast as priority development opportunities. The strategic role that is currently given to urban soil management as a key determinant of spatial planning decisions evokes an essay published by Bernardo Secchi in the late 1980s: Progetto di Suolo, the "project for the ground" (Secchi, 1986). In this seminal writing, the urbanist criticizes that, during the 20th century, urban soils were insufficiently conceptualized, represented and projected through the graphic productions and designs of the discipline. He affirms that soil's spatial and functional dimensions are essential to the understanding of contemporary cities and suggests that they should be considered as a new paradigm for the urban project.

In this context, urban soils, which include remnants of natural soils as well as a large proportion of 'Anthrosols' and 'Technosols,' as described in the World Reference Base for soil resources (IUSS Working Group WRB, 2006), can no longer be reduced to an idealized or neutralized surface. On the contrary, as products and agents of environmental and human history, urban soils must be documented in light of the processes which they support and are supported by, both in a retrospective and prospective way. In the first place, they represent a highly complex three-dimensional material that developed as a long-lasting legacy of heavy anthropization (Barles, Breysse, Guillerme, \& Leyval, 1999). The predominance of anthropized substrate generates relatively 'young' transitioning soils, on which pedogenetic processes may, in some cases, resume actively and rapidly over the course of a few decades. Consideration for urban soils must therefore account for their future developmental stages (Burghardt, 2001; Leguédois et al., 2016). In addition to these significant historical characteristics, geographer Claude Raffestin refers to open soils embedded within urban structures as "an anti-hazard system mechanism" or "a time pocket" (Raffestin, 1989, p. 186). These phrases underline the various functions of urban soils and the role they will have to play in the future of cities, as protections against increasing environmental risk and as a potential resource for forthcoming social and ecological transitions. Besides food and biomass production, soils have the capacity to deliver localized ecosystem services (Dominati, Patterson, \& Mackay, 2010) that are essential for maintaining the habitability of cities (Economic and Social Council, 2019), by absorbing storm water, mitigating local effects of climate change, containing contaminants, capturing and storing carbon, and supporting biodiversity, among other functions (Morel, Chenu, \& Lorenz, 2014). A time dynamic ap- proach to urban soils should therefore inform the various ongoing interdisciplinary initiatives that integrate soil's multi-functionality as a driver for spatial planning (City of Stuttgart, 2012; Grêt-Regamey, Kool, \& Kissling, 2018; Robert, 2012). In the purpose of implementing such an evolutionary and multifunctional 'project for the ground,' two main knowledge gaps must be addressed.

On the one hand, accurate methodology is needed so that researchers, stakeholders and designers can properly survey urban soil's quantitative and qualitative diversity, based on rapidly evolving general knowledge about human impacted soils and their specific features (Craul, 1992; Howard, 2017; Lal \& Stewart, 2017; Levin et al., 2017). The anthropic influence on soils in the urban environment is conditioned by architectural and infrastructural interventions stratified over many historical periods. This anthropic space and time scale generates extreme spatial and chronological variability, which cannot be entirely explained by the landscape-soils models traditionally used in soil science and originally developed to study natural ecosystems (Burghardt, 1994). In the last three decades, mostly for North American and Central European cities, soil scientists have therefore produced so-called 'concept maps' in order to facilitate the very difficult task of empirically surveying urban soils (Burghardt, Morel, \& Zhang, 2015). This kind of map serves to overcome several technical and organizational difficulties in urban soil mapping, to determine deductively the boundary of individual soil units and potential associated properties, and provide a digital platform for further operational uses (Schneider, 2000). However, the conceptual frame of urban soil concept maps remains rudimentary, due to the lack of a supervised model that would extensively articulate the various kinds of urbanization-related influences on soils relative to natural pedogenetic processes (Leguédois et al., 2016). Such maps are usually limited to roughly superimposed past land use and contemporary evidence of landforms' evolution (Howard, 2017; Lal \& Stewart, 2017; Levin et al., 2017).

On the other hand, it is necessary to clarify the planning and design rules by which a 'project for the ground' could today reactivate the qualities and functions of the urban soils that we have inherited, according to a coherent and sustainable vision articulated at different scales. Among other natural resource management processes, the successive processes of soil transformation through deforestation, cultivation, mining, infrastructure development and urban settlement have ensured the habitability of the territory over time (Secchi, Viganò, \& Fabian, 2016). These land reclamation efforts successively correspond to coherent cultural, social and technical projects throughout history (Mantziaras \& Viganò, 2016). The evolution of these "geocultural settings" (Howard, 2017, p. 11) have generated complex territorial and spatial patterns which partially overlap as a "palimpsest" (Corboz, 1983). Facing the heterogeneity of contemporary urban territory, ongoing zoning policies, which are formulated in terms of stock, surface 
and perimeter, struggle to overcome a solely conservative approach based on an oversimplified and divisive urban/rural dichotomy (Viganò, Barcelloni Corte, \& Vialle, in press). The lack of a conceptual model that fully integrates the agency of spatial development and urbanism with regards to soil development, the likes of which has been developed for other ecosystem services (Jaligot, Chenal, Bosch, \& Hasler, 2019), reduces urban soils to static objects. On the contrary, lan McHarg defines, in his seminal book Design with Nature (McHarg, 1969, p. 103), the notion of "process as value" as a fundamental paradigm of the ecological planning discipline. Such a statement, which equates the evolutionary processes of landscapes and functional qualities of territories with social, if not economical, values, has not yet been transitioned to soil formation in anthropogenic ecosystems. The implementation of more innovative strategies playing on both the evolution of urban forms and soil functionalities over time (Berger, 2006; Corner, 2006; Kennen \& Kirkwood, 2015; Orff, 2016; Spirn, 1984) is consequently hampered.

In order to fill these epistemological and methodological gaps, this article will highlight the human history of urban soils by (I) synthetizing a causal chain model of urbanization, and its related project, as a crucial factor of pedogenetic processes and by, (II) retracing urban soils' specific historical trajectories according to a cartographic narrative constructed from various source documents. This dynamic vision will be explored through the creation of an atlas based on the case study of West Lausanne district in the canton of Vaud, Switzerland. Our approach aims at extending the concept map used by soil scientists to the framework of advanced urbanism, by bridging spatial planning with the fields of historical ecologies (Amossé et al., 2014; Beller et al., 2017; Sanderson, 2009) and layered spatial analysis (McHarg, 1969), based on innovative remote sensing and four-dimensional data management techniques. Such consolidated concept mapping underscores the usefulness and applicability of different types of information and analytic operations for documenting various human-induced soil evolution processes. It also reveals the extreme spatial variability and chronological versatility found in soils by linking them to both the distribution of urban patterns and the evolution of urbanization techniques. The gradually decreasing influence of site condition and increasing anthropic dominance on soils' evolution are therefore explained more systematically. In turn, retracing urban soils' development pathways reveals the logics that have informed the evolution of a 'project for the ground' and also contributes to the definition of soil quality as a dynamic and co-variable value of urban morphologies and uses. Spatial planning and urbanization can therefore be considered not only as a threat to soil capital, but also as a means through which it is possible to act intentionally in order to valorize this resource. Ultimately, establishing a causal link between the current physical state of a soil and the transformations it has undergone through urban- ization helps to predict and potentially guide the future influence of spatial planning policies and land management practices on soils' functionality.

In sum, this article will exemplify that drawing spatial sections through the vertical depth of soils as a humaninfluenced living material, and transects through the horizontal variations of soils as a support for human habitat, enables the construction of a retrospective and prospective time sequence spanning the history of both their graphic documentation and physical transformation as a more or less intentional design-project.

\section{A Theoretical Framework and Methodology for the Study of Anthropedogenesis as a Coevolution Process}

The $9 \times 4.5 \mathrm{~km}$ extent of the atlas covers a large portion of the eight municipalities forming the $25.81 \mathrm{~km}^{2}$ West Lausanne district, encompassing the hills of the Swiss Plateau in the north to Lake Geneva in the south. This longitudinal transect crosses several heterogeneous ecological milieus, each associated with various geological features shaped by the Rhone Glacier, such as molassic outcrops, morainic, glacio-lacustrine and fluvio-glacial superficial deposits. The East/West boundaries of the atlas correspond to a transversal gradient from the edge of Lausanne historical center towards the periphery of its metropolitan area. The soils in this area have been affected by gradual dismantling of a landscape previously dominated by agriculture, starting with industrialization in the 19th century and including tertiarization, periodic high-rate population growth, as well as implementation of large-scale transport and sanitation infrastructure. Today, this mixed-used district has 57,000 jobs and 75,500 residents, with a residential density of 2,925 inhabitants per square kilometer. This territory still retains a large amount of cultivated and/or undeveloped land, the future of which is the subject of a planning policy currently in development.

How can the general influence of such an anthropized ecosystem on its soils be understood? Soil scientists Dan Yaalon and Daniel de Richter evoke the concept of soil as a "human-natural body" (p. 767) in terms of a "mutual co-genesis, with soil and humanity developing jointly and interactively" (Yaalon \& de Richter, 2011, p. 775). The anthropic transformation of soils, coined as 'anthropedogenesis,' not only stratifies soils' parent material, but also permanently reprocessed it into what is, here again, referred to as a 'palimpsest' by many soil scientists (Vialle \& Verrecchia, 2018). Yaalon and de Richter define consequently soil changes according to three coexisting and superimposing "overlapping time scales":

The multi-millennial natural soil system...; the historic soil system, affected by both natural processes and legacies of human impact usually lasting up to several thousands of years...; and the contemporary humanaffected system, affected by natural and historic processes and ongoing management typically for less 
than 100 years. (Yaalon \& de Richter, 2011, p. 768; see Figure 1)

Our case study will focus on the emergence of the contemporary anthropized soils system, corresponding to West Lausanne urbanization over the last century. It is therefore necessary to transition the conceptual model of natural pedogenesis in order to integrate the logics of urbanization to this framework. Pedology comprehends soil transformation according to Jenny's model (Jenny, 1941) defining five external state factors of pedogenesis-climate, biology, topography, lithology or parent material (PM), and time-the influence of which can be studied in the form of a sequence. The combinations of these factors trigger different pedogenetic processes, leading to various soil evolution or development pathways (DP) including specific biogeochemical charac- teristics and associated functional properties, which can be interpreted as ecosystem services.

Following Yaalon and Yaron (1966), numerous authors (i.a. Burghardt, 1994, 2001; Burghardt et al., 2015; Effland \& Pouyat, 1997; Huot et al., 2017; Leguédois et al., 2016) discussed the human influence on soils in relation to Jenny's external state factor model and revealed that the impact on PM through anthroturbation is of primary importance. This influence at the Earth's surface is indeed straddling between constructional and destructional landforms (Riddle \& Levin, 2017). In the first case, superficial anthropic deposits, or anthrosediments, are moved horizontally, while in the second case, human-altered soils are modified only vertically in place. This distinction between the geological and pedological levels in the delineation of the anthropogenic footprint determines whether human influence is to be consid-

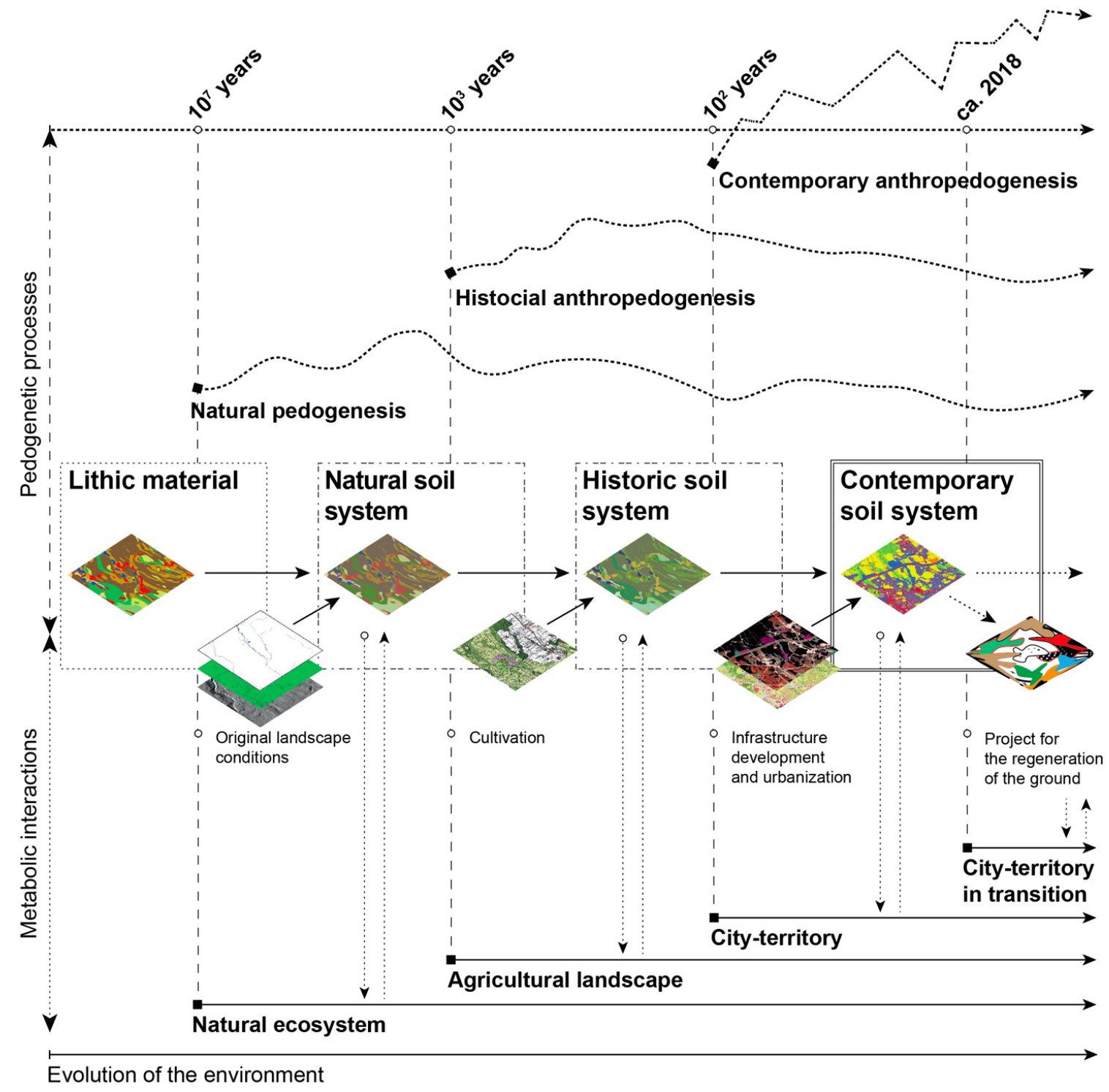

Figure 1. Diagram of human-nature pedogenesis: from top to bottom, coexisting and superimposing time scales, processes of polygenesis, soil systems and corresponding factors, interactions with natural-anthropic environments. Source: Authors, after Yaalon and de Richter (2011). 
ered as an independent and additional lithogenetic state factor, or as an interdependent biological state factor. In the first case, neopedogenesis is defined as a shortterm anthropic intervention, such as cut and fill, that "resets the pedological clock" (e.g., Schaetzl \& Thompson, 2015 , p. 299) by external disruption of the preexisting soil profile which becomes new PM. Natural pedogenetic processes may resume on new PM in pseudonatural or human-altered combinations. In the second case, metapedogenesis is defined as a longer lasting intervention, such as ploughing, that doesn't interrupt the internal soil development happening on a constant PM, but modifies the resulting profile by chronically or cyclically changing the intensity and combination of pedogenetic processes. In addition to the primary influence of changes in the soil material regime linked to topography and lithology state factors, urbanization induces other impacts on soils, such as sealing or modification of the vegetal cover. These impacts lead to changes in the water, and fauna-flora regimes (Burghardt, 2017a; Leguédois et al., 2016) respectively linked to the climate and biology state factors. Although they have been relatively little studied so far, it is now acknowledged that such disturbances also modify the intensity and combination of pedogenetic processes (Burghardt, 2017b).

The above-mentioned authors (i.a. Burghardt, 1994, 2001; Burghardt et al., 2015; Effland \& Pouyat, 1997; Huot et al., 2017; Leguédois et al., 2016) agree that urban soils are byproducts of combined natural and anthropogenic factors interacting on different time scales and modifying the intensity and extent of pedogenetic processes which, nevertheless, remain natural. Results presented and discussed in this article will show that soil management practices and morphological patterns related to urbanization adapt to the different components of the landscape and, in turn, transform them. However, urbanization-induced factors also evolve over time, according to technical and socio-cultural logics. This evolution explains why anthropic land uses are gradually taking precedence over natural factors in soil evolution and how they define new functional links and flows between soils (Burghardt, 2017a).

We propose to synthesize the diverging combinations of this causal chain in the form of a flow chart diagram presenting various representative trajectories, which depend on urban history and which will be exemplified below. Among the different urbanization-related changes in soil conditions documented in the atlas, at least seven main urban soil historical trajectories can be identified (see Figure 2). The various biogeochemical impacts on soils in the course of these trajectories generate specific pedogenetic processes, which trigger or deviate various soil DP. Trajectory A (Traj. A) is characterized by permanence of natural landscape conditions as predominant state factors. In this case, pedogenesis occurs on original PM without disturbance, and the soil follows a natural DP. Traj. B is characterized by the establishment of agricultural or horticultural use, then eventually other landscaping maintenance practices, which chronically modifies natural factors. Metapedogenetic processes occur on original soil, following a deviated DP determined by both natural and anthropic metafactors. Traj. $\mathrm{C}$ is characterized by punctual alteration and/or displacement of soil material, or even complete destructuration of the original soil profile as in the case of the construction of an urban structure and/or related earth disposal. Neopedogenetic processes resume on anthrosediments as modified or new PM, following a pseudo-natural but deviated DP which is determined by both natural factors and anthropic lithogenesis, with less influence of preexisting geomorphological conditions. Traj. D is similar to Traj. C, but with drastic PM alteration, such as strong compaction or change in soil geochemical composition. Neopedogenesis resets at a much lower rate, or in different combination, following a deviated DP mostly determined by anthropic lithogenesis as external factor. Traj. E is a combination of Traj. B and Traj. C characterized by both punctual alteration of PM due to construction, then chronic modification of natural factors due to cultivation. Metapedogenetic processes occur on modified or new PM, following a deviated DP determined by both anthropic lithogenesis and metafactors, with less influence of preexisting geomorphological conditions. Traj. F is characterized by sealing, causing both punctual alteration of PM and drastic chronical modification of natural factors. Pedogenesis resumes at a very low rate on new PM, following a slow or nearly inert DP which is mostly determined by anthropic lithogenesis and the quality of the sealed layer. Finally, Traj. $G$ is characterized by soil stripping following the establishment of building foundations on bedrock. Destruction of PM and maintenance of the built structures temporarily annihilates the necessary conditions for pedogenesis by precluding the formation of new PM by aerial deposition.

The conceptual causal chain model and the trajectories elaborated above define the various links of a soil ecosystem compartment model (Burghardt, 1994): spatial planning decisions distributed in time and space; natural and anthropic factors of pedogenesis; pedogenetic processes and soil DP; and the resulting soil profile and associated properties. As a spatial transcription and case application of this model, the atlas is a consolidated cartographic device composed of various layers (Schneider, 2000). The relations by which the layers inform each other were determined by a workflow of mapping operations consisting of various graphic/analogical spatial analyses (Makowsky \& Schneider, 2017). The workflow consists of the following steps (see Figure 3 ).

Various soil-related information sources were compiled into three base layers corresponding to the interacting natural and anthropic state factors. Base layer I Geomorphology represents the geological formations and their specific reliefs, the geotypes (Parriaux \& Turberg, 2007), which correspond to lithology, topography and major hydrological systems, as a synthesis of preexisting landscape conditions. It gives an idea of pre- 


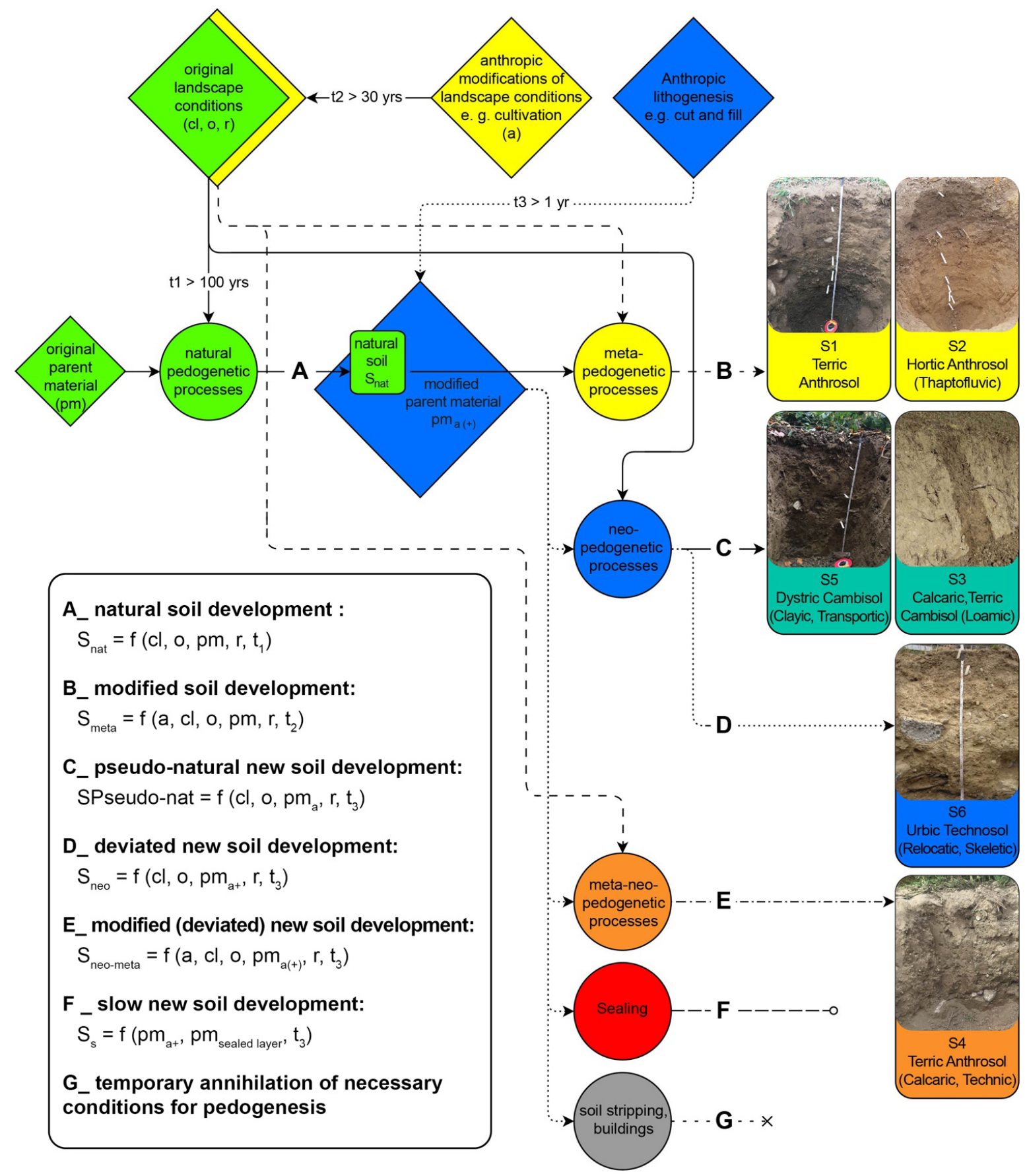

Figure 2. Causal chain conceptual model of anthropedogenesis. Source: Authors, after Yaalon and Yaron (1966), Effland and Pouyat (1997), and Yaalon and de Richter (2011), with photos from UNINE-UNIL Biogeoscience Master's Degree, Fall 2018.

existing natural soils and anthropogenic superficial deposits which partially reflect the changes in the material and water regimes. Base layer II Land cover represents spontaneous and man-managed vegetation, which corresponds to the biological factor strongly modified by cyclical soil maintenance practices as an overarching metafactor, as well as sealed and built surfaces, which correspond to changes in material and water regime. Base layer III Anthrosediments focuses on the various urban structures implemented in the area, the construction of which correspond to changes in material regime through anthropic punctual lithogenesis as neofactor. These base layers were separated into historical map series in order to trace the evolution of factors across space and time as an urban anthroposequence of pedogenesis. Such intermediary outcomes explain the agency of the 'project for the ground' on soils' evolution according to past and future spatial planning decisions. Based on the anthroposequence supplemented by soil profile descriptions, the various combinations of natural and anthropic fac- 


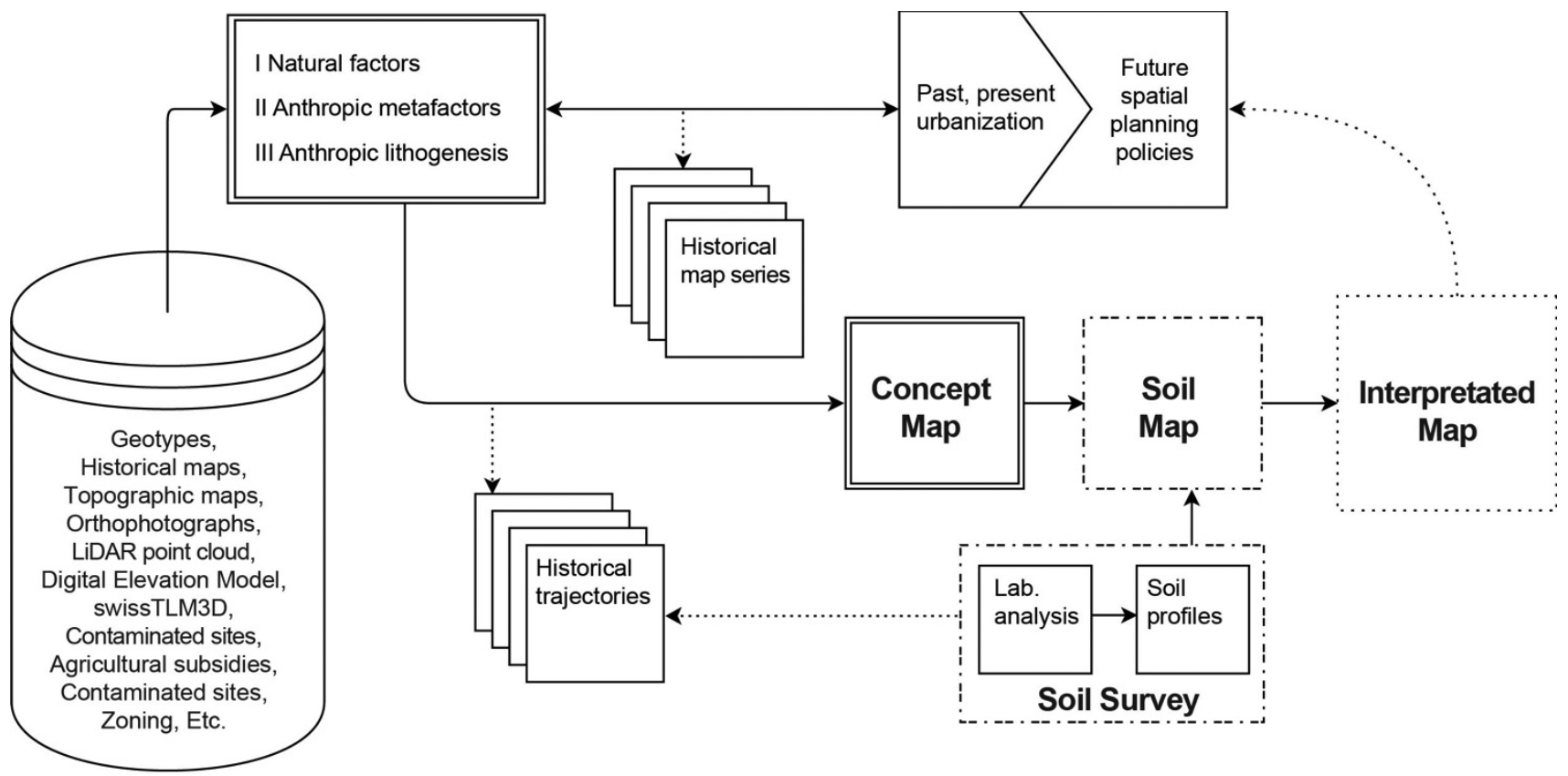

Figure 3. Workflow including source documents and outcome layers informing each other according to various mapping operations. Source: Authors.

tors were finally synthesized into a new concept map to spatialize the main soil historical trajectories, effectively distilling the workflow presented in this article.

\section{Mapping Time: Aggregating Datasets into a Four-Dimensional Platform for an Historical Reconstruction of Urban Developments and Land Cover Changes}

On the soil map of the canton of Vaud (Canton de Vaud, n.d.), as well as on those produced at the national level by the Federal Office for Agriculture (Geocat.ch, n.d.), urban areas appear as white spots, illustrating a fairly common epistemological gap (Hernandez et al., 2017; Makowsky \& Schneider, 2017; Van De Vijver, Delbecque, Verdoodt, \& Seuntjens, 2020). Documents collected from various private and government sources are therefore required to overcome the dearth of available soil data for this case study. They revealed a fluctuating practical and cultural consideration for soil.

Two sets of hand-drawn topographic maps (DAVEL, n.d.) produced at the municipal scale and respectively dated ca. 1830 and ca. 1880-1900 (further mentioned here as 1900) at a $1: 10,000$ to $1: 5,000$ depict in detail the texture of the ground, without establishing any hierarchical distinction between the elements belonging to the natural, agricultural and urban realms. In such documents, the land cover, and therefore how the soil is used, appears as a central feature of landscape and territorial management. Each village is depicted as a coherent spatial entity, among which wilderness, human habitat and agronomic productivity are of equal importance (see Figure 4a). In different versions of a na- tional topographic map (Federal Office of Topography swisstopo, n.d.-b, n.d.-c, n.d.-d) which successively appeared at a scale gradually decreasing from 1:100,0000 in 1840 to $1: 10,000$ today, land cover is no longer represented per se, as a continuous element with a varying texture. Focus is instead given to urban developments and infrastructures that stand out against an abstract background (see Figure 4b). Orthophotographs (Federal Office of Topography swisstopo, n.d.-a) and picturesque postcard-type views (Bonzon, Marendaz, \& Pahud, 1987; Marendaz, 2007) supplement these maps and provided a new medium of territorial representation. As opposed to maps, these intrinsically anecdotal documents mechanically record valuable if unintentional information about anthropic impact on soils, such as the spatial coexistence of rural, industrial and urban activities, or the actual footprint of large construction sites (see Figure 4c). Finally, today the most recent developments in remote sensing techniques provide new datasets initially developed primarily for risk management. In particular, airborne light imaging, detection, and ranging (LiDAR) point clouds combined with orthophotography provide a refined classification which can be used to distinguish sealed soils from open ones, as well as different vegetation strata (Gachet, 2013). Continuous land cover is therefore available at an unprecedented centimetric resolution, which is comparable to the aforementioned municipal maps (see Figure 4d).

These compiled documents where rasterized, georeferenced, and classified in a geographic information system (GIS) according to a consistent classification system at a 1:10,000 scale. This process allowed for comparison between categorical layers and across temporal group- 


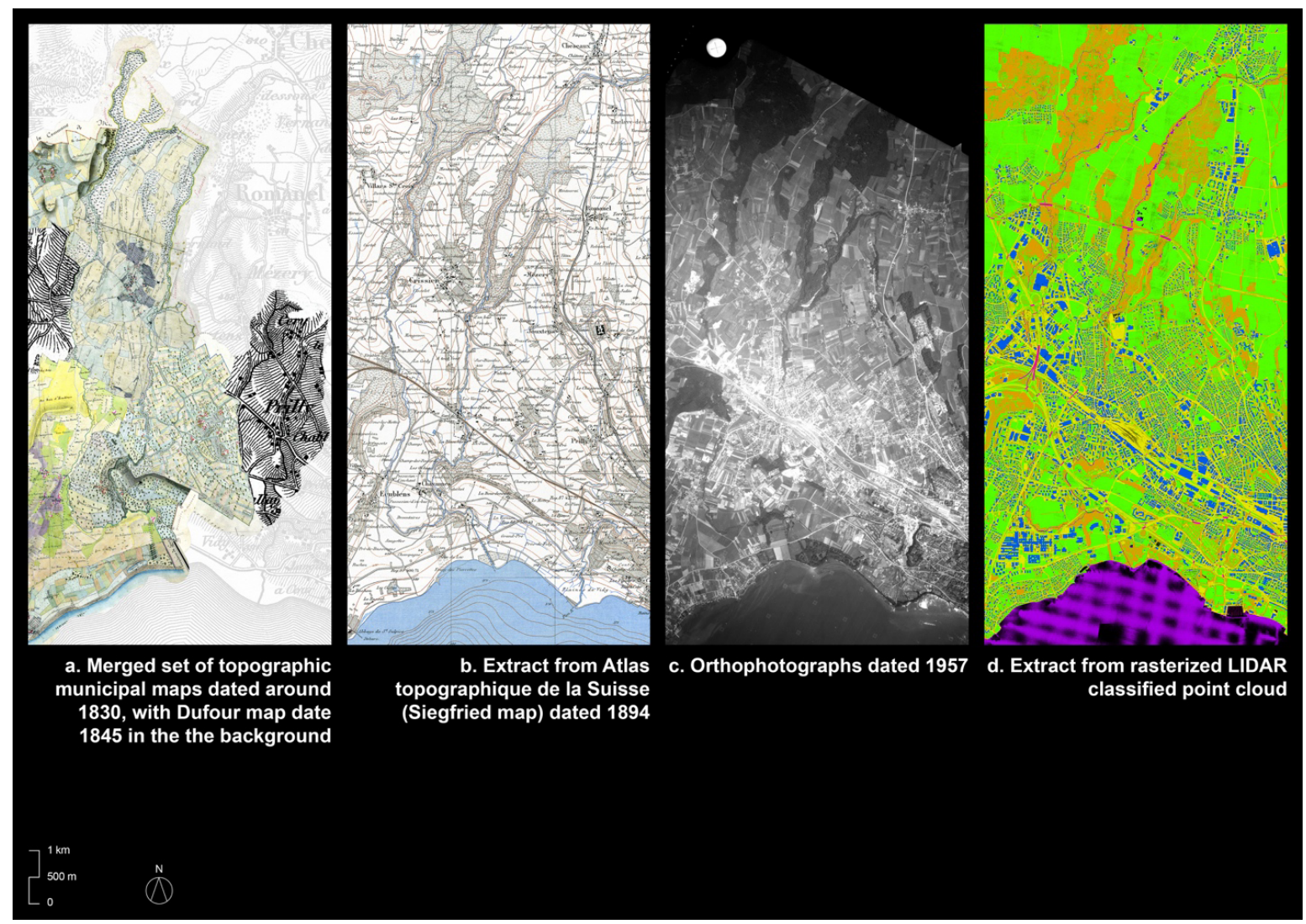

Figure 4. Examples of source documents available through time. Source: Authors, based on geodata and archival sources provided by Archives Cantonales Vaudoises, Swisstopo, and Canton de Vaud-Office de l'information sur le territoire.

ing. Following the evolution of knowledge on soil and its representation through various mediums, such a chronological approach then produced an original cartography integrating history as a fourth dimension of the map, tracing urban development and land cover transformation within the study area.

While the information in base layer I Geomorphology (see Figure $5 \mathrm{a}$ ) comes from a single source (Association pour le Système d'information du Territoire, n.d.), base layers II and III were elaborated from a combination of various source documents. Base layer II Land cover contains two maps corresponding to the end of the 19th century (see Figure 6a) and to the contemporary period (see Figure $6 \mathrm{~b}$ ). A unique classification was established based on the rudimentary legend accompanying the communal maps (see Figure 6d), with the term 'garden' used to designate open soil surfaces in the immediate vicinity of homes, without distinction between ornamental greenery, non-subsidized food producing uses, or vacant lots. Base layer III Anthrosediments (see Figure 7a) contains 11 non-exhaustive types of urban structures which have generated anthrosediments and therefore potentially impacted urban soil PM. The extent of anthrosediments was determined by the effective footprint of an urban structure, the diffusion of its impact around it according to a buffer estimated from historical orthophotographs, or based on the right-of-way of a functional entity or landholding, such as a parcel.
Base layer I remains relatively stable over the study time period, with the notable exception of major anthropic changes in the topography related to urbanization further documented in base layer III. Therefore, this layer was not separated into a proper historical map series. However, its classification into five main categories of geotypes does give a sense of the multi-million year time scale of geomorphological processes (see Figure $5 b$ ). In turn, the historical map series that comprise base layers $I /$ and III are sequenced according to a unique timeline. The sequence starts in 1830 , which corresponds to the earliest available municipal maps, at which point West Lausanne was still a rural landscape, and terminates in 2018, which corresponds to the current state of urbanization. Intermediate stages on the timeline were determined in order to properly cover the main waves of urban growth and infrastructure development.

The urban structures represented in base layer III were dated according to their first emergence on the historical source documents. A color-code was assigned to each of the 11 elements. Taking inspiration from the more or less long exposure of photographic paper to light in order to graphically represent a chronological gradient, the intervals of the timeline were transposed in seven shades of a grey. Such a typological and chronological (see Figure 7d) sequencing created a bivariate choropleth map, which allows both a diachronic (see Figure 7b) and synchronic (see Figure 7c) interpretation. 


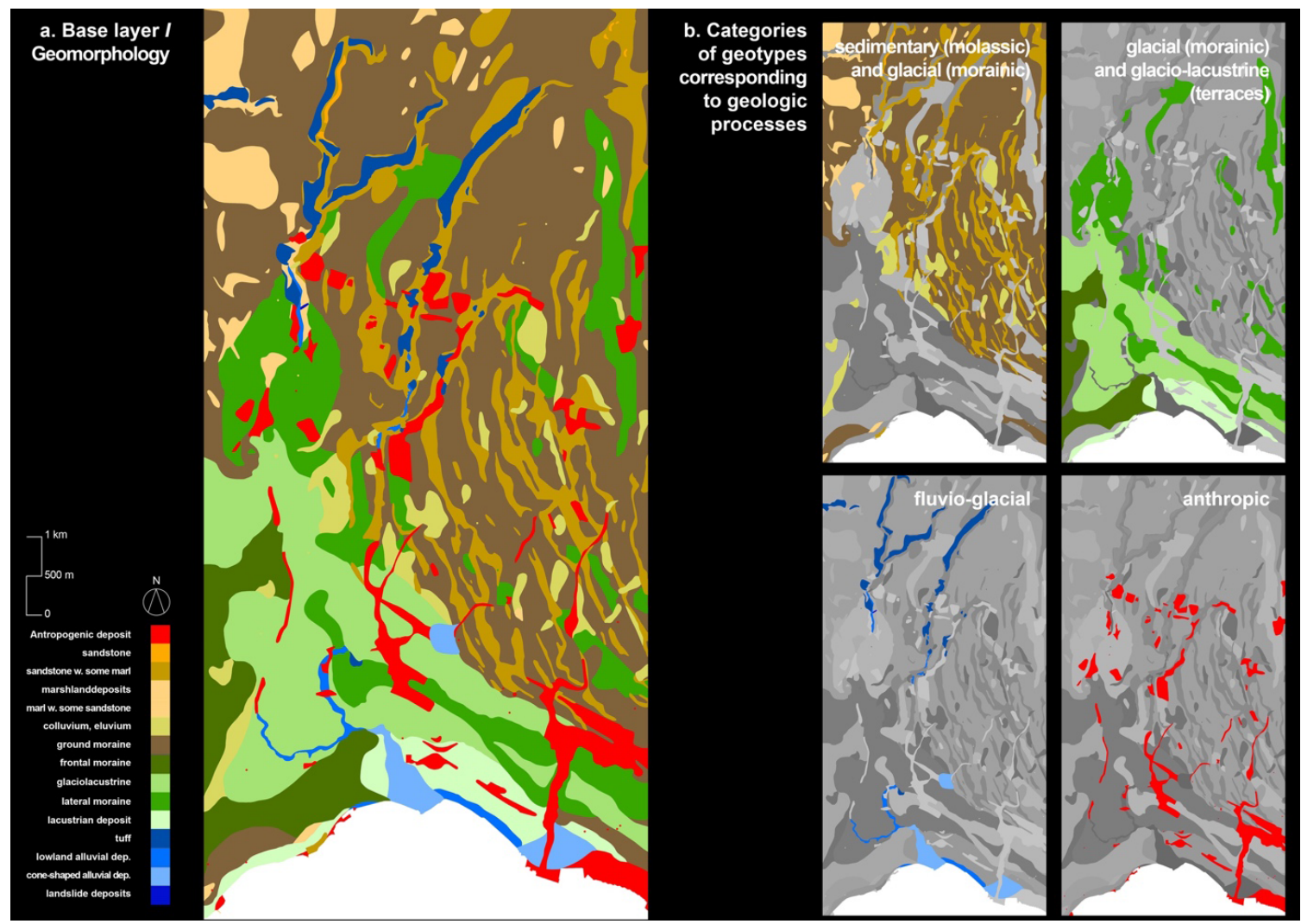

Figure 5. Base layer I. Source: Authors, based on geodata provided by Canton de Vaud-Office de l'information sur le territoire.

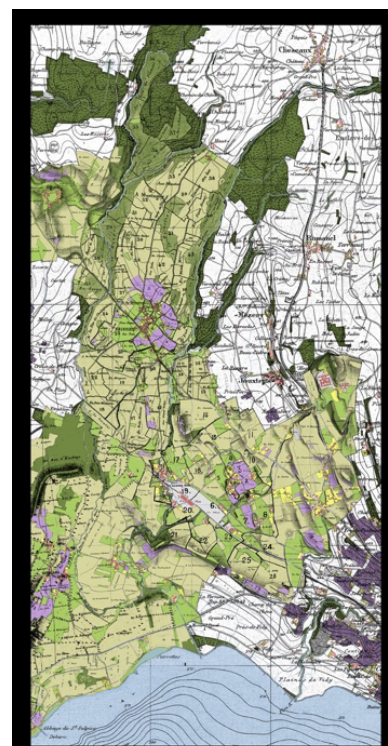

a. Base layer II Land cover before 1900

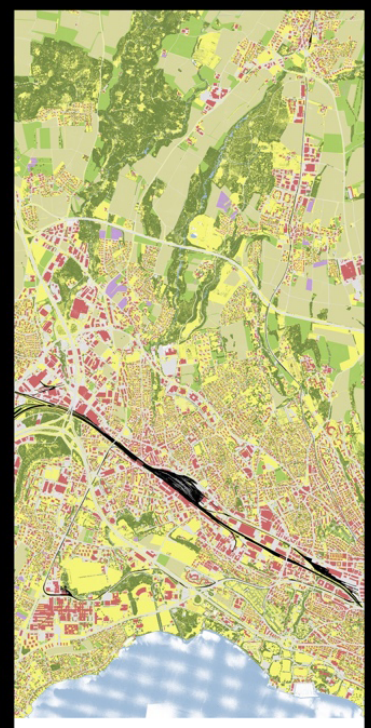

b. Base layer II Land cover ca. 2018

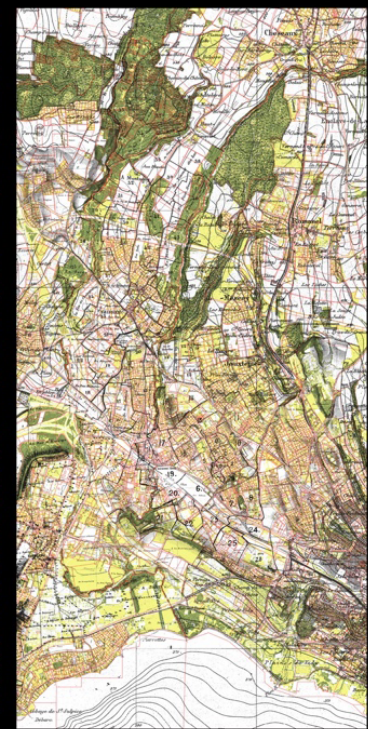

c. Complete garden historical series

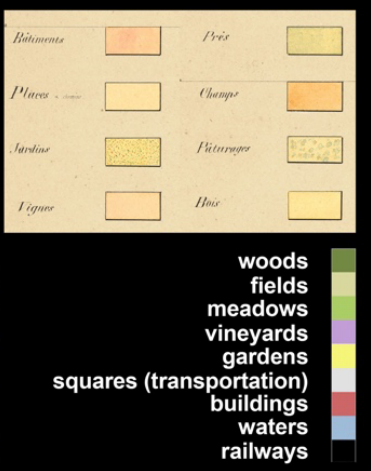
superimposed to forme agricultural land holdings

gardens

woods

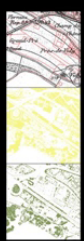

d. From top to bottom: Original legend found in the Carte de Saint-Sulpice dated 1904-1906; Legend of base layer $I$; Legend of garden historical series

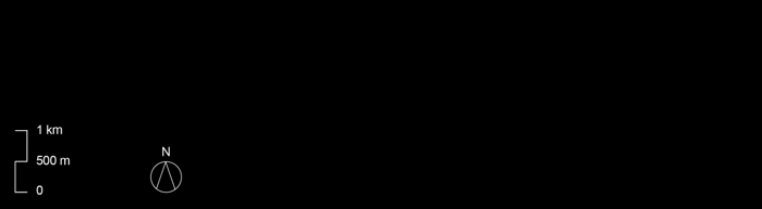

of ga 


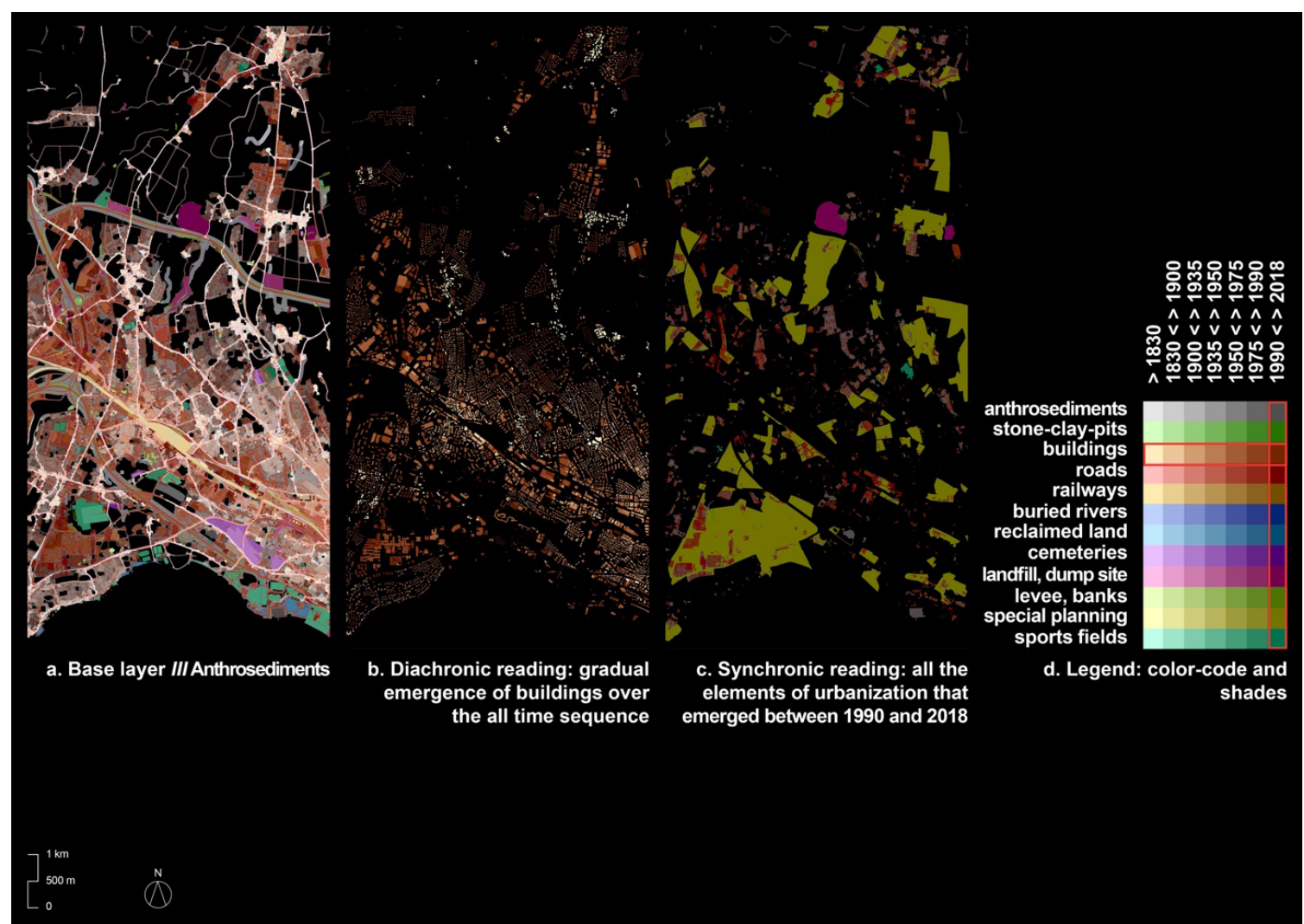

Figure 7. Base layer III. Source: Authors, based on geodata provided by Swisstopo and Canton de Vaud-Office de l'information sur le territoire.

The historical sequencing of base layer I/ was limited to a comparative analysis between its two stages of evolution in order to determine land cover permanence, disappearances and emergences. If the historical reconstruction and dating operations performed on layer III allow for an incremental reading of urbanization as an evolutionary process, the comparative analysis provides for an interpretation of land cover evolution in terms of disruption. We therefore sought to go beyond this first interpretation by trying to better understand the incremental process which produced the disaggregation of the initial agricultural landscape. For each interval of the time sequence, the former agricultural land holdings represented in the municipal maps were superimposed with the contemporary plot division, which was dated according to the time on which each plot was gradually urbanized and turned into a 'garden' (see Figure 6d). This operation provides us with a second historical map series (see Figure $6 \mathrm{c}$ ) retracing the diachronical emergence of the 'garden' as an ambiguous typology of land cover, in relation to the dismantling and reconversion of former agricultural land holdings.

\section{Connecting Soils' Contrasted Development Pathways to Historical Trajectories: An Urban Anthroposequence}

If placed side by side, the 'anthrosediments' and 'garden' map series can also be read synchronically, in order to correlate the specificities of both land cover changes and urbanization processes for each time period. Such a reading provides an integrated vision on the chronological evolution of the anthropic factors impacting urban soils. The two historical map series were therefore used along with empirical profile descriptions to exemplify and to locate in space and time the typical soil trajectories mentioned above. In order to highlight anthropogenic lithogenesis and metapedognenesis, the research focused on profile descriptions of various soils corresponding to Traj. B, Traj. C, Traj. D and Traj. E. The impacts observed on these soil profiles in the context of historical urbanization processes informs our understanding of soil DP.

Until the end of the 19th century, the West Lausanne region was characterized by a 'project for the ground' in the form of a mesh of villages, which is clearly depicted in the historical municipal maps. These small urban entities were distributed equidistantly, located in the center of the municipal territory and surrounded by successive belts of gardens, vineyards, meadows and fields, taking advantage of the geomorphological characteristics of each site. However, the diachronic reading of each map series placed side by side shows that during the first half of the 20th century (see Figure 8), a diffuse and mixed urbanization logic was established. Agriculture, industry and housing were gradually closely intertwined throughout the entire southern part of West Lausanne, crossed 

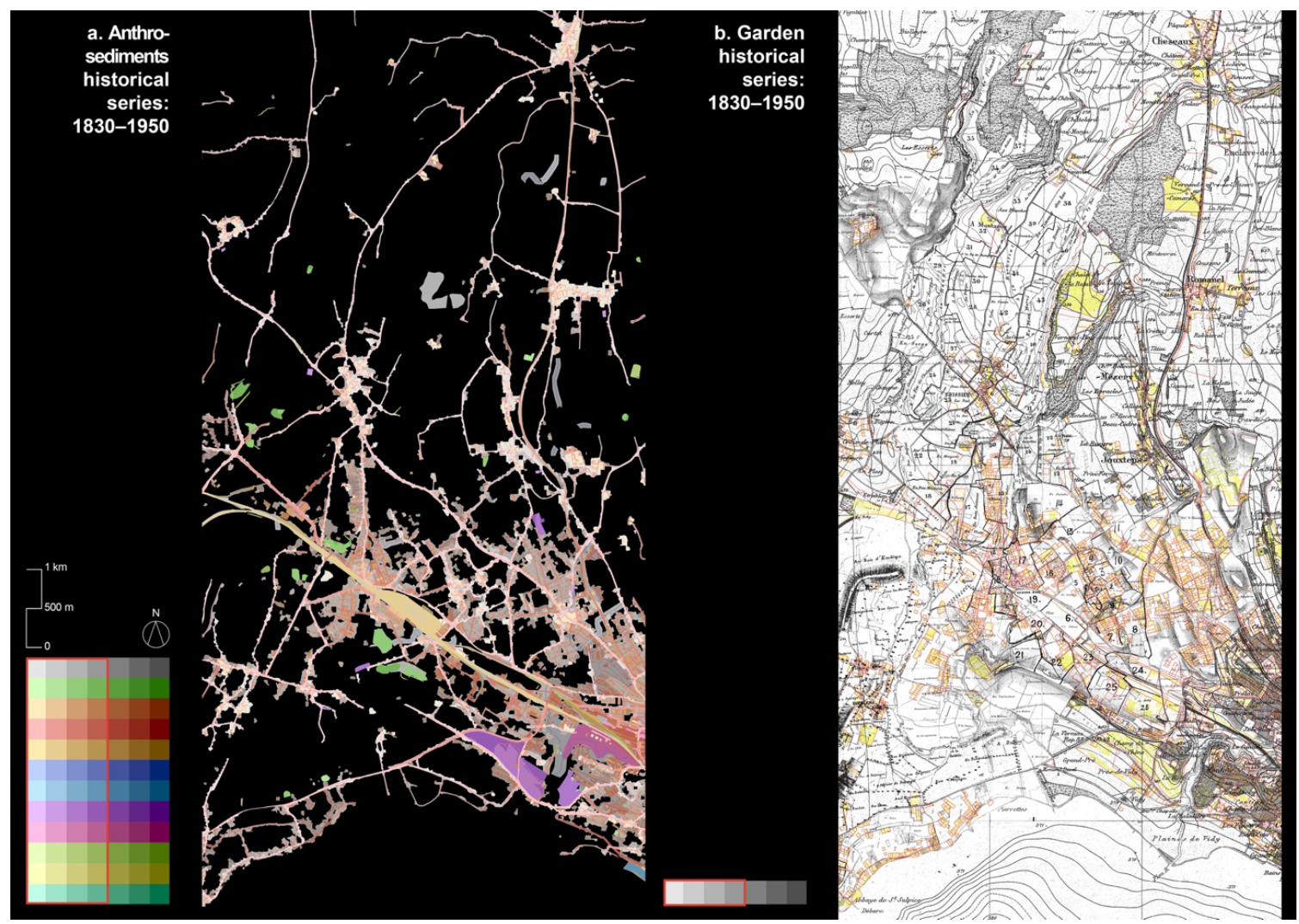

Figure 8. First half of the 20th century: Historical map series of base layers II and III. Source: Authors.

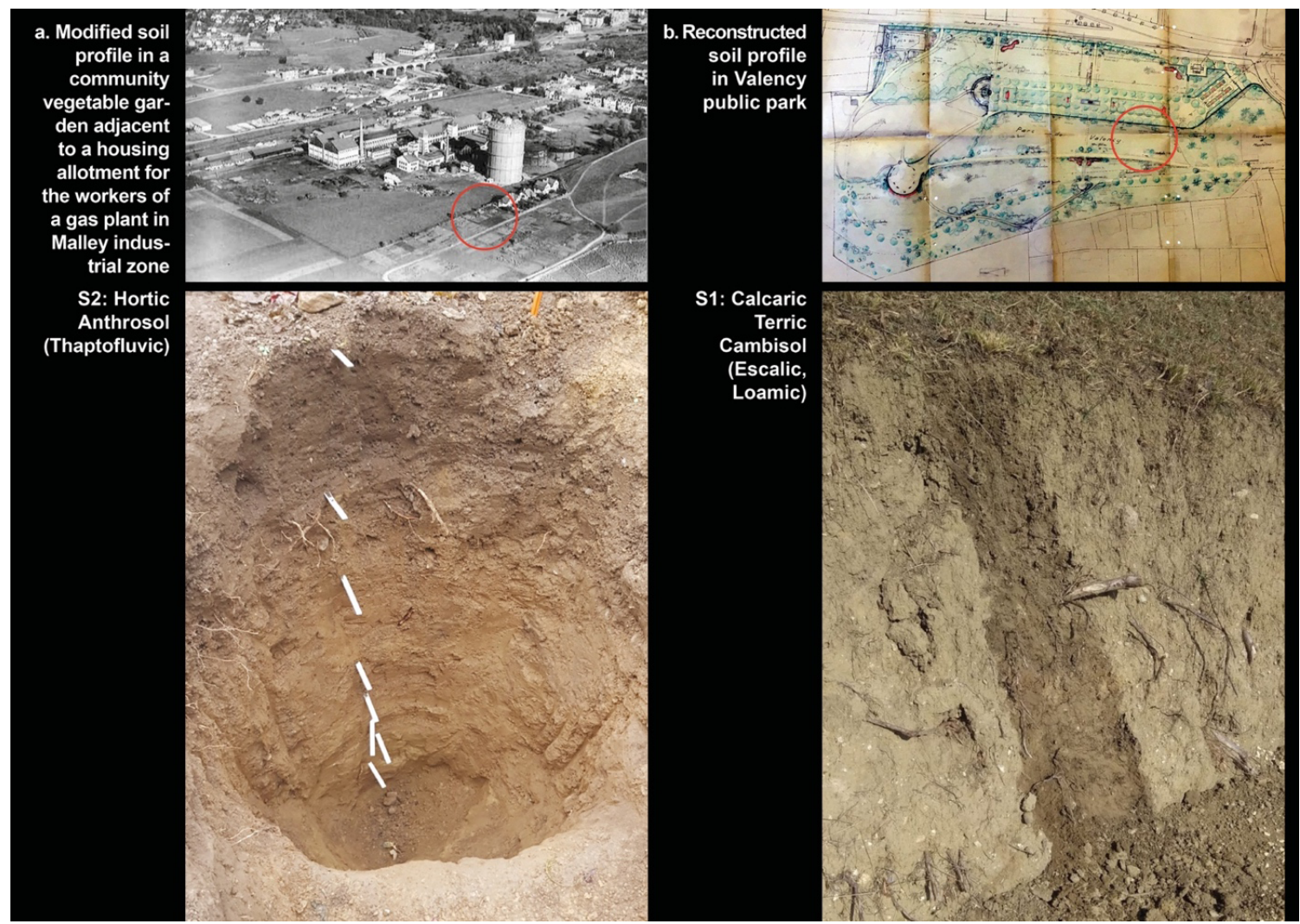

Figure 9. First half of the 20th century: Soil profiles, accompanied by historical source documents illustrating the urbanization processes which produced them. Source: Authors, based on photos and archival sources provided by Marendaz Collection, Ville de Lausanne-Service des parcs et domaines, and UNIL-UNINE Biogeoscience Master's Degree, Fall 2018. 
on its central axis by new railway lines. This process of urbanization was essentially structured by the creation of roads and developed according to land opportunities plot by plot. Such close-scale operations tend to preserve the productive role of open spaces often dedicated to domestic food production in the immediate vicinity of new dwellings. Such traditional use of soil corresponding to Traj. B is illustrated by a profile we have excavated in a community vegetable garden adjacent to a worker housing allotment in the Malley industrial zone (see Figure 9a). Although it is located in the heart of the city in an area that has been urbanized for a century, the soil profile's physical qualities are minimally impacted. Its original structure, linked to fluvio-glacial geological processes, remains intact, with no major earthwork or compaction, but only a thin layer of fertile material added in the upper part of the profile which is characterized by a high organic matter content. On the chemical level, however, laboratory analysis shows the soil has been subject to pollution from neighboring industries and long-lasting horticultural practices. Another soil profile, excavated in Valency public park which was created in the 1940s, was subjected to notable landscaping including earth tipping (see Figure 9b). However, it can be observed that the addition of earth materials was carefully implemented thanks to relatively unobtrusive technical means, which allowed for a rapid resumption of natural biogeochemical processes according to Traj. C.

During the second half of the 20th century (see Figure 10), the characteristic fabric of West Lausanne was then restructured through fast-growing housing developments and tertiarization. This period was marked by the construction of major infrastructures, such as the first Swiss highway, and larger sectorized operations (i.e., large housing or office complexes, a university campus, logistics or recreational platforms). Such evolution was made possible by the introduction of special planning tools, which facilitated the gradual dismantlement of agricultural land holdings, starting with larger 'bourgeois' estates, and then smaller horticultural units. This modernist urban planning project for the ground conferred soils of new landscaped green spaces a highly ornamental, recreational, and hygienic value, albeit at the expense of their former productive functions. Therefore, as shown in historical orthophotographs, it is not surprising that more invasive building techniques, affecting the whole surface of each development site by a global management of cut and fill material, had a much greater impact on soil quality. Examples of this increased anthropic impact can be observed in two soils situated on the university campus and in an agricultural field along the highway embankment (see Figure 11). In both profiles, the disregard for soil quality is indicated by the presence of a layer of miscellaneous construction site waste which had been 'hidden' under a reconstituted topsoil. These two highly compacted tipped soils present a lower level of biogeochemical activity than those mentioned previously, although they have been restructured more re- cently and are now respectively dedicated to extensive park and agricultural uses, following Traj. D and Traj. E.

In the context of urban history, such examples of soil trajectories allow us to examine the influence of urbanization on soil in different ways. First, a spatial variation in urban development according to geomorphology and associated topography has been observed along the North/South transect. Until the end of the 19th century, for example, villages and vineyards were generally established on hillsides, while woods were preserved mainly on the steepest slopes along rivers. Since the end of the 19th century and during the 20th century, major transportation infrastructure, industrial platforms and campuses were mainly located in lower sunken reliefs, corresponding to a glacio-lacustrine geomorphology. However, these correlations tend to diminish with more major anthropogenic modification of the original landscape, such as river burying, as well as with recent developments progressively covering the urban fabric. Our case study, which covers an intermediate area between Lausanne historic city center and Vaud canton's rural area, also shows that the greatest anthropic impact on soils cannot be interpreted in a linear East/West or center/periphery gradient. Indeed, the soil profile displaying the highest level of chemical contamination, yet with relatively intact horizonated structure, is located in one of the most central and oldest industrialized locations; whereas the most compacted tipped soil, also displaying the highest content of technogenic artefacts, is located in one of the most peripheral and recently developed locations (see location of the soils studied in Figure 12a). These empirical observations are in line with the idea currently accepted within the field thatcontrary to historic city centers characterized by homogeneity of highly impacted anthropogenic substrate, more dispersed and/or contemporary forms of settlements, such as West Lausanne-display more heterogeneous soil conditions (Burghardt, 1994; Hernandez et al., 2017; Howard, 2017; Huot et al., 2017; Prokof'eva \& Martynenko, 2017). Framing conditions in terms of center/periphery gradient, as well as simple land-use categories, are therefore relevant in macro-perspectives. Yet, when applied to close territorial reading, they should be reconsidered in favor of more sophisticated spatial patterns such as, in our case, a diffuse and mixed urbanization, interweaving villages, agriculture, industry and sectorized developments within a mesh which was gradually densified.

Rather than by a simple spatial transect or gradient, the influence of urbanization on West Lausanne soils can therefore be mainly explained by a section through time. Such an historical narrative integrates various facets of land use, including construction and maintenance techniques, planning tools, and urban morphologies, into a specific 'project for the ground' which urban historian André Corboz designates as Swiss Plateau "city-territory" (Corboz, 1990, pp. 631-635). The atlas therefore offers a template, in the form of a complex figure in both time 

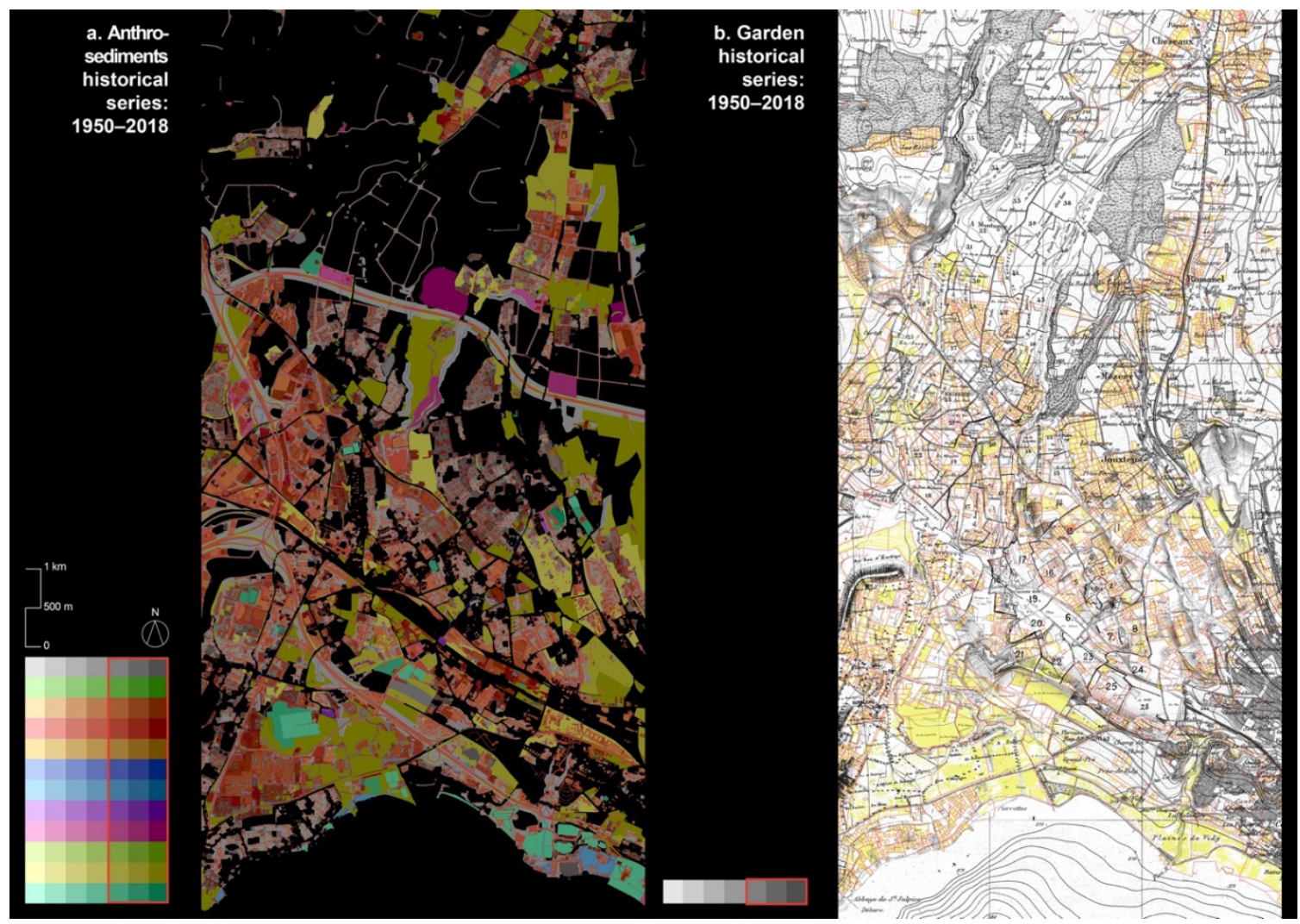

Figure 10. Second half of the 20th century: Historical map series of base layers II and III. Source: Authors.

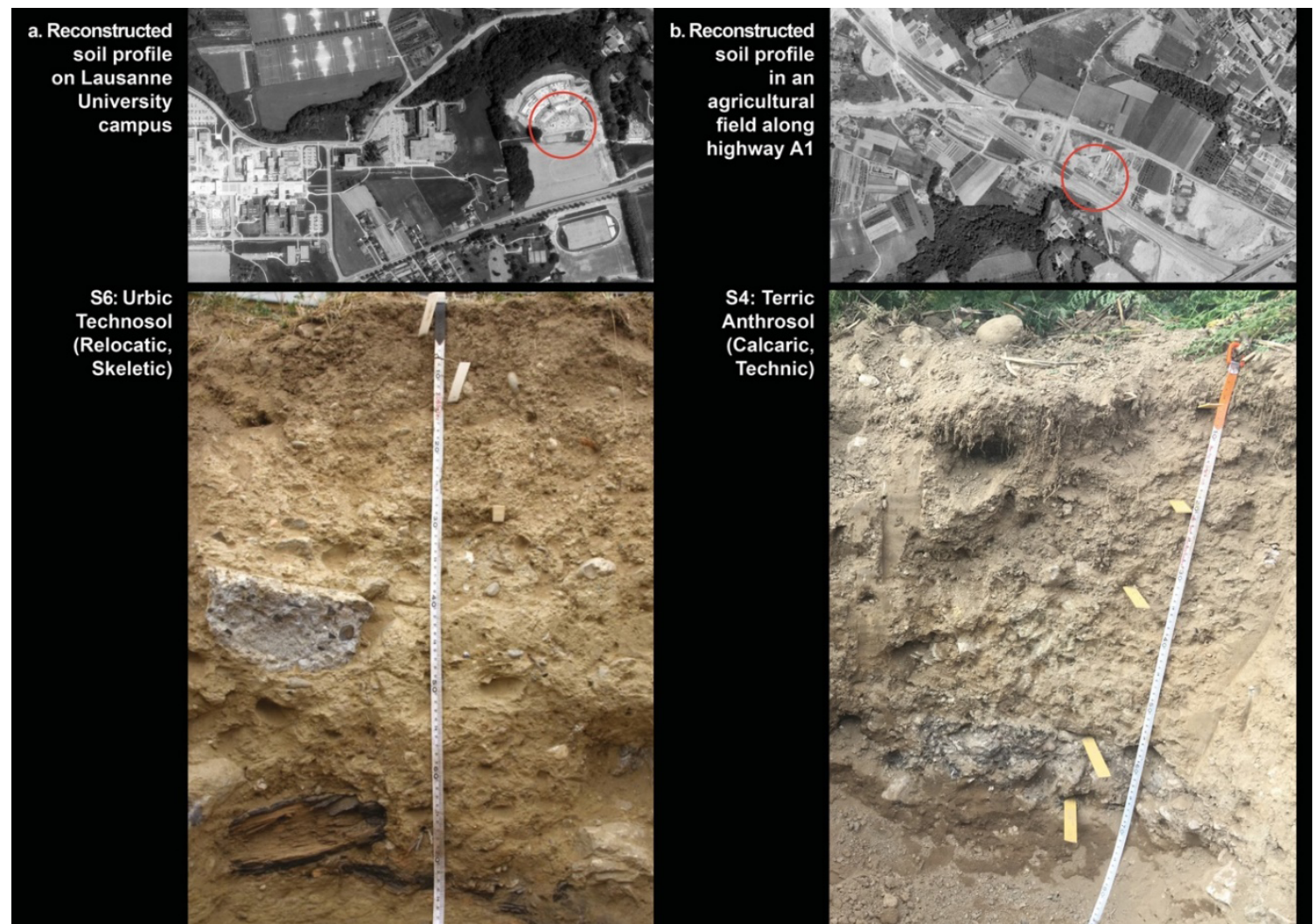

Figure 11. Second half of the 20th century: Soil profiles, accompanied by historical source documents illustrating the urbanization processes which produced them. Source: Authors, based on photos and archival sources provided by Swisstopo, and UNIL-UNINE Biogeoscience Master's Degree, Fall 2018. 


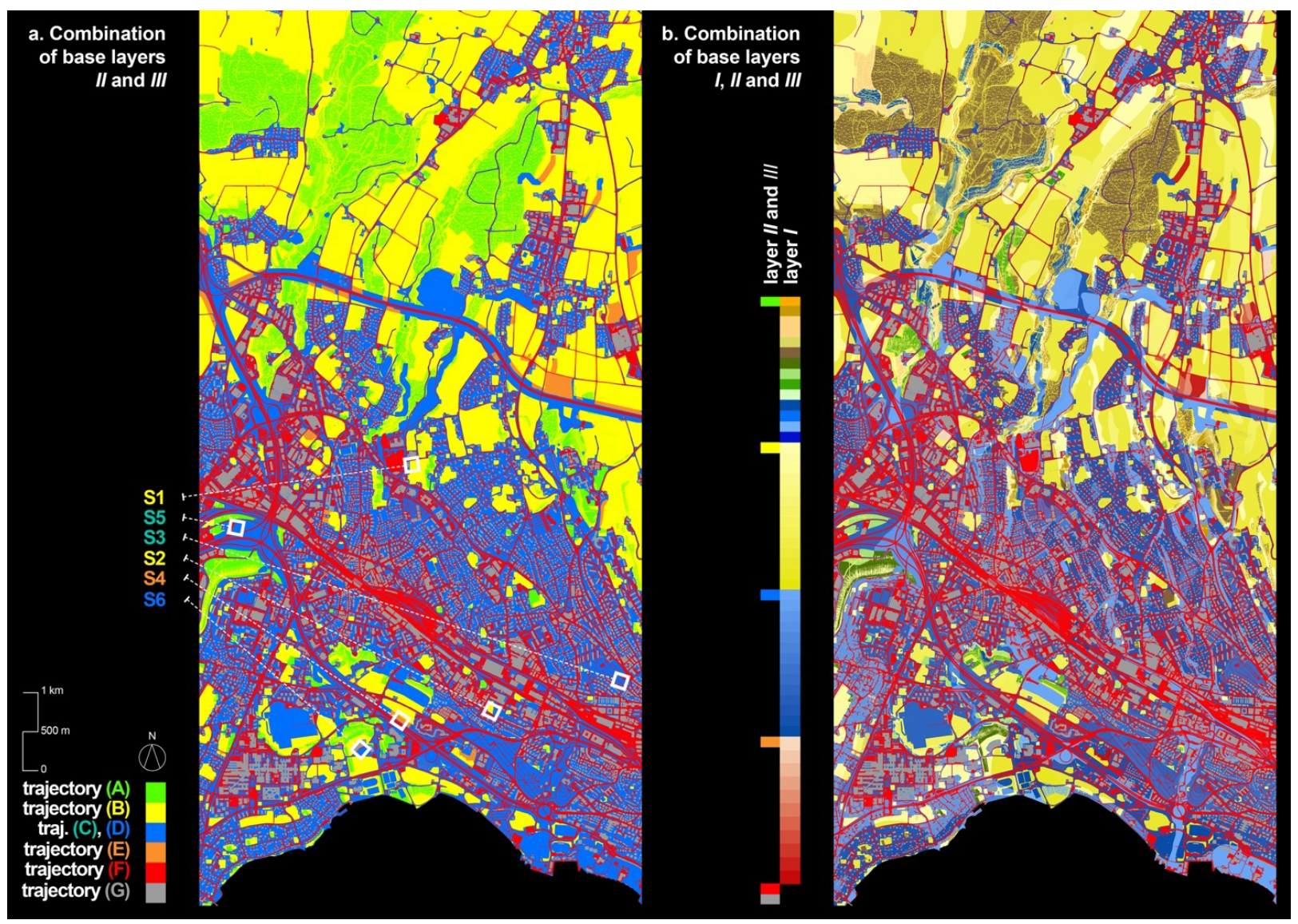

Figure 12. Draft concept map of potential urban soils, including the location of the soils studied. Source: Authors.

and space, on which to apply the factor approach in order to explain the variation of contrasted soil DPs as a coherent bundle of historical trajectories. In this respect, our case study demonstrates the theoretical validity of an urban anthroposequence of pedogenesis (Effland \& Pouyat, 1997).

At this stage of the research, we can therefore consider the possibility of extrapolating, at the territorial scale of West Lausanne, a concept map of potential urban soils based on a supervised classification of soil historical trajectories a priori. A first draft of such a map is obtained by combining the information about anthropogenic meta-and neo-state factors of pedogenesis contained in the base layers I/ and III through their sequencing as historical series of maps, with only Traj. C and Traj. D remaining undifferentiated (see Figure 12a). A second draft supplement the first one by introducing the preexisting landscape conditions synthesized in base layer I (see Figure 12b).

Although statistically substantiated in previous case studies (Schneider, 2000), the validity of the concept map should be demonstrated through the collection and classification of a greater number of soil samples and profile descriptions. Such empirical survey would ensure iterative improvement of the conceptual model and its application to the concept map though historical trajectories. In particular, empirical survey is necessary to properly determine the actual quality of altered soil PM and to verify the location of potential informal cultivation practices. Empirical survey would finally allow us to obtain a proper urban soil map, by associating specific soil properties to the map units and therefore by defining soil volume characterized by constant profile, designated as pedons or polypedons (see dashed boxes in Figure 3 ).

\section{Conclusions: Foreseeing the Interrelated Regenerations of Both West Lausanne City-Territory and Its Urban Soils}

In the forthcoming developments of the research, the urban soil map could be interpreted in terms of soil functionalities and their related capacity to deliver ecosystem services. As envisioned by several authors (City of Stuttgart, 2012; Grêt-Regamey et al., 2018; Robert, 2012), such an interpreted map would therefore allow for the assessment of the relevance of current zoning principles from the perspective of actual soil functionality in relation to the estimated future need for ecosystem services (see dotted boxes in Figure 3). More importantly, such a functional approach could lead to the development of alternative strategies to business-as-usual. As required by the imperative inward urbanization principle, the dynamic and systemic vision induced by the coevolution of the city-territory and its soils outlines oppor- 
tunities for the requalification and valorization of both the specific urban fabric of West Lausanne and its urban soil mosaic.

Indeed, from land and ground to four-dimensional soils, the consolidation of theoretical and practical knowledge regarding the agency of punctual and chronical urban practices on soil development would point toward potential positive impacts on urban soil capital. Based on our historical study, we can assume that current decisions on urban planning and design will result in land use changes, corresponding to the establishment of new land covers and related recurring maintenance practices, as well as new urban structures and related anthrosediments. If guided by a comprehensive project for the regeneration of the ground, these future prototypical trajectories could lead to the expression of alternative soil DPs which could potentially improve the quality and multifunctionality of inherited urban soils. This continued evolution could lead to alternative planning scenarios.

In this respect various resource deposits can be identified from the atlas. For instance, the 20th century productive platforms, which are now extensively mineralized, would have to be reconditioned. The heterogenous 'garden,' the formation of which accompanied diffuse urbanization, could be reworked as a fine grain local network. Finally, the open soils still in agricultural use, which, according to the actors interviewed for this study, constituted a 'reserve' during the process of gradual infill of the urban mesh, could now be envisioned as an ecological reserve and territorial green infrastructure. Urban reconversion and improvement to urban soils' functionality would therefore imply innovative processes based on reclaiming soil trajectories. Large-scale de-sealing would lead to a shift from abovementioned Traj. F to Traj. C. The implementation of regenerative agricultural, horticultural, and ornamental open soil maintenance practices would shift soils from Traj. B or Traj. D to a more resilient Traj. B' or Traj. C.

The elaboration of such strategies rests in the understanding of both West Lausanne city-territory and its urban soils as 'palimpsests.' As a snapshot in time, such composite images contain reprocessed material evidences of spatiotemporal evolutions, whose trajectories were retraced here as an urban anthoposequence in a time-dynamic map series.

\section{Acknowledgments}

The case study presented here was conducted in the frame of a PhD thesis at the Laboratory of Urbanism (Lab U) of École polytechnique fédérale de Lausanne (EPFL) by Antoine Vialle, under the co-direction of Prof. Paola Viganò (EPFL, Lab U) and Prof. Éric Verrecchia (Université de Lausanne [UNIL], Institute of Earth Surface Dynamics [IDYST]), as part of a research project entitled "Our common soils: The Swiss City-territory as a renewable resource" and funded by the Swiss National
Science Foundation (SNSF). The case study was carried out in Fall 2018 with the help of students of the UNIL - UNINE Biogeoscience Master's Degree, under the direction of Prof. Éric Verrecchia assisted by Ludovico Formenti, Dimitri Rigoussen, Michael Rowley and Antoine Vialle, and partially elaborated in the frame of a SNSF-sponsored visiting studentship at the Massachusetts Institute of Technology, Norman B. Leventhal Center for Advanced Urbanism, under the supervision of Prof. Alan Berger, with the collaboration of Mario Giampieri. The case study benefited from the insights of Prof. Christophe Schwartz (University of Lorraine-INRA, Laboratoire Sols et Environnement) and Dr. Marj Tonini (UNIL, IDYST).

\section{Conflict of Interests}

The authors declare no conflict of interests.

\section{References}

Amossé, J., Jelmini, J.-P., Havlicek, E., Mitchel, E. A. D., Le Bayon, C., \& Gobat, J.-M. (2014). Mille ans d'extension urbaine à Neuchâtel: Évolution des paysages et des sols [A millenium of urban expansion in Neuchâtel: Evolution of landscapes and soils]. Bulletin de La SNSN, 134, 45-66.

Association pour le Système d'information du Territoire. (n.d.). Carte des géotypes. Association pour le Système d'information du Territoire. Retrieved from https://www.asitvd.ch/index.php?option=com_ easysdi_catalog\&view $=$ sheet\&guid $=643 \&$ catalog $=$ main\&type $=$ complete\&preview=search_list

Barles, S., Breysse, D., Guillerme, A., \& Leyval, C. (Eds.). (1999). Le sol urbain [The urban soil]. Paris: Anthropos.

Beller, E., McClenachan, L., Trant, A., Sanderson, E. W., Rhemtulla, J., Guerrini, A., . . \& \& Higgs, E. (2017). Toward principles of historical ecology. American Journal of Botany, 104(5), 645-648. https://doi.org/ 10.3732/ajb.1700070

Berger, A. (2006). Drosscape: Wasting land in urban America. Princeton, NJ: Princeton Architectural Press.

Bonzon, A., Marendaz, J.-C., \& Pahud, C. (1987). L'ouest lausannois à la belle époque de la carte postale [West Lausanne in the "belle époque" of the postcard].

Burghardt, W. (1994). Soils in urban and industrial environments. Zeitschrift für Pflanzenernährung und Bodenkunde, 157(3), 205-214. https://doi.org/ 10.1002/jpln.19941570308

Burghardt, W. (2001). Soils of low age as specific features of urban ecosystem. In J. Sobocka (Ed.), Soil anthropization. VI Proceedings, International Workshop, Bratislava, 20-22 June 2001. Bratislava: Soil Science and Conservation Research Institute.

Burghardt, W. (2017a). Main characteristics of urban soils. In M. J. Levin, K.-H. J. Kim, J.-L. Morel, W. 
Burghardt, P. Charzynski, R. K. Shaw, \& IUSS Working Group SUITMA (Eds.), Soils within cities. Global approaches to their sustainable managementComposition, properties, and functions of soils of the urban environment. Stuttgart: Schweizerbart.

Burghardt, W. (2017b). Soil sealing-Ways, constraints, benefits and management. In M. J. Levin, K.-H. J. Kim, J.-L. Morel, W. Burghardt, P. Charzynski, R. K. Shaw, \& IUSS Working Group SUITMA (Eds.), Soils within cities. Global approaches to their sustainable management-Composition, properties, and functions of soils of the urban environment. Stuttgart: Schweizerbart.

Burghardt, W., Morel, J. L., \& Zhang, G.-L. (2015). Development of the soil research about urban, industrial, traffic, mining and military areas (SUITMA). Soil Science and Plant Nutrition, 61(sup1), 3-21. https:// doi.org/10.1080/00380768.2015.1046136

Canton de Vaud. (n.d.). Guichet cartographique cantonal. Canton de Vaud. Retrieved from https://www.geo.vd. ch/theme/sols_thm

City of Stuttgart. (2012). Urban soil management strategy: Soil in the city. Stuttgart: Department for Environmental Protection.

Corboz, A. (1983). Le territoire comme palimpseste [Territory as palimpsest]. Diogène, 31(121), 12-34.

Corboz, A. (1990). Vers la ville-territoire [Towards the cityterritory]. In Sonderdruck aus Ergänzungen Ergebnisse der wissenschaftlichen Tagung anlässlich der Einweihung des Ergänzungsbaus der Hochschule St. Gallen (pp. 631-635). Bern: Haupt.

Corner, J. (2006). Terra fluxus. In C. Waldheim (Ed.), The landscape urbanism reader. Princeton, NJ: Princeton Architectural Press.

Craul, P. J. (1992). Urban soil in landscape design. Hoboken, NJ: John Wiley \& Sons.

Daniels, R. B., \& Hammer, R. D. (1992). Soil geomorphology. Hoboken, NJ: John Wiley \& Sons.

DAVEL. (n.d.). Inventaires des archives cantonales vaudoises. DAVEL. Retrieved from http://www.davel.vd. ch/archivplansuche.aspx

Dominati, E., Patterson, M., \& Mackay, A. (2010). A framework for classifying and quantifying the natural capital and ecosystem services of soils. Ecological Economics, 69(9), 1858-1868.

Economic and Social Council. (2019). Report of the Secretary-General, Special edition: Progress towards the Sustainable Development Goals. New York, NY: United Nations.

Effland, W. R., \& Pouyat, R. V. (1997). The genesis, classification, and mapping of soils in urban areas. Urban Ecosystems, 1(4), 217-228. https://doi.org/10.1023/ A:1018535813797

European Commission. (2016). No net land take by 2050? (Future Brief No. 14). Brussels: European Commission. Retrieved from https://ec.europa.eu/ environment/integration/research/newsalert/pdf/ no_net_land_take_by_2050_FB14_en.pdf
Federal Office of Topography swisstopo. (n.d.-a). A journey through time-Aerial images. Federal Office of Topography swisstopo. Retrieved from https://www.swisstopo.admin.ch/en/maps-dataonline/maps-geodata-online/journey-throughtime-images.html

Federal Office of Topography swisstopo. (n.d.-b). Background information on the Dufour Map. Federal Office of Topography swisstopo. Retrieved from https://www.swisstopo.admin.ch/en/knowledgefacts/histcoll/historical-maps/dufour-map.html

Federal Office of Topography swisstopo. (n.d.-c). National map 1:10 000. Federal Office of Topography swisstopo. Retrieved from https://www. swisstopo.admin.ch/en/knowledge-facts/maps-andmore/new-national-maps/national-map-10000.html

Federal Office of Topography swisstopo. (n.d.-d). Background information on the Siegfried map. Federal Office of Topography swisstopo. Retrieved from https://www.swisstopo.admin.ch/en/knowledgefacts/histcoll/historical-maps/siegfried-map.html

Gachet, G. (2013). Délimitation des espaces verts sur la commune de Lausanne [Delimitation of green spaces in the municipality of Lausanne]. Lausanne: Canton de Vaud, Office de l'information sur le territoire (OIT), Section géodonnées.

Gardi, C. (2017). Urban expansion, land cover and soil ecosystem services. Abingdon: Routledge. https:// doi.org/10.4324/9781315715674

Geocat.ch. (n.d.). Digital soil suitability map of Switzerland [Data set]. Retrieved from https://www.geocat. ch/geonetwork/srv/eng/md.viewer\#/full_view/ 4d7ea1c8-451b-46b6-8e16-ffee10e0c9a7/tab/ complete

Grêt-Regamey, A., Kool, S., \& Kissling, S. (2018). NRP 68 thematic synthesis report 3: A soil agenda for spatial planning. Bern: Swiss National Science Foundation.

Häberli, R., Lüscher, C., Praplan Chastonay, B., \& Wyss, C. (1991). L'affaire sol: Pour une politique raisonnée de l'utilisation du sol. Rapport final du Programme National de Recherche "Utilisation du sol en Suisse" (PNR 22) [The Soil Case: For a Reasoned Land Use Policy. Final Report of the National Research Program "Land use in Switzerland" (NRP 22)]. Chêne-Bourg: Georg éditeurs.

Hernandez, L., Levin, M. J., Calus, J., Galbraith, J., Muñiz, E., Ryan, K., . . . \& Lindbo, D. (2017). Urban soil mapping through the United States national cooperative soil survey. In R. Lal \& B. A. Stewart (Eds.), Urban soils. Boca Raton, FL: CRC Press. https://doi.org/10.1201/ 9781315154251

Howard, J. (2017). Anthropogenic soils. Berlin: Springer. https://doi.org/10.1007/978-3-319-54331-4

Huot, H., Séré, G., Vidal-Beaudet, L., Leguédois, S., Schwartz, C., Watteau, F., \& Morel, J.-L. (2017). Pedogenic processes in soils of urban, industrial, traffic, mining and military areas. In M. J. Levin, K.-H. J. Kim, J.-L. Morel, W. Burghardt, P. Charzynski, R. K. 
Shaw, \& IUSS Working Group SUITMA (Eds.), Soils within cities. Global approaches to their sustainable management-Composition, properties, and functions of soils of the urban environment. Stuttgart: Schweizerbart.

IUSS Working Group WRB. (2006). World reference base for soil resources 2006. World soil resources reports (No. 103). Rome: FAO.

Jaligot, R., Chenal, J., Bosch, M., \& Hasler, S. (2019). Historical dynamics of ecosystem services and land management policies in Switzerland. Ecological Indicators, 101, 81-90. https://doi.org/10.1016/j.ecolind. 2019.01.007

Jenny, H. (1941). Factors of soil formation: A system of quantitative pedology. New York, NY: McGraw-Hill.

Kennen, K., \& Kirkwood, N. (2015). Phyto: Principles and resources for site remediation and landscape design. Abingdon: Routledge.

Lal, R., \& Stewart, B. A. (Eds.). (2017). Urban soils. Boca Raton, FL: CRC Press. https://doi.org/10.1201/ 9781315154251

Leguédois, S., Séré, G., Auclerc, A., Cortet, J., Huot, H., Ouvrard, S., . . \& \& Morel, J. L. (2016). Modelling pedogenesis of technosols. Geoderma, 262, 199-212. https://doi.org/10.1016/j.geoderma.2015.08.008

Levin, M. J., Kim, K.-H. J., Morel, J.-L., Burghardt, W., Charzynski, P., Shaw, R. K., \& IUSS Working Group SUITMA (Eds.). (2017). Soils within cities. Global approaches to their sustainable managementComposition, properties, and functions of soils of the urban environment. Stuttgart: Schweizerbart.

Makowsky, L., \& Schneider, J. (2017). The case of Germany. In M. J. Levin, K.-H. J. Kim, J.-L. Morel, W. Burghardt, P. Charzynski, R. K. Shaw, \& IUSS Working Group SUITMA (Eds.), Soils within cities. Global approaches to their sustainable managementComposition, properties, and functions of soils of the urban environment. Stuttgart: Schweizerbart.

Mantziaras, P., \& Viganò, P. (Eds.). (2016). Le sol des villes: Ressource et projet [The soil of cities: Resource and project]. Geneva: Métispresses.

Marendaz, J.-C. (2007). Renens: De la campagne à la ville [Renens: From countryside to city]. Renens: JCMarendaz.

McHarg, I. L. (1969). Design with nature. New York, NY: Natural History Press.

Morel, J.-L., Chenu, C., \& Lorenz, K. (2014). Ecosystem services provided by soils of urban, industrial, traffic, mining, and military areas (SUITMAs). Journal of Soils and Sediments, 15(8), 1659-1666. https://doi. org/10.1007/s11368-014-0926-0

Orff, K. (2016). Toward an urban ecology. New York, NY: The Monacelli Press.

Parriaux, A., \& Turberg, P. (2007). Les géotypes, pour une représentation géologique du territoire [Geotypes, for a geological representation of the territory]. Tracés, 15/16, 11-17.

Prokof'eva, T. V., \& Martynenko, I. A. (2017). The case of Moscow, Russia. In M. J. Levin, K.-H. J. Kim, J.-L. Morel, W. Burghardt, P. Charzynski, R. K. Shaw, \& IUSS Working Group SUITMA (Eds.), Soils within cities. Global approaches to their sustainable management-Composition, properties, and functions of soils of the urban environment. Stuttgart: Schweizerbart.

Raffestin, C. (1989). Eléments pour une théorie du sol [Elements for a soil/land theory]. In Communauté d'études pour l'aménagement du territoire (Ed.), La construction sous contrôle? Faut-il renforcer ou alléger l'aménagement pour mieux gérer les zones à bâtir? Journées romandes de l'aménagement du territoire, Lausanne, les 10 et 11 novembre 1988 (pp. 185-189). Lausanne: Presses polytechniques romandes.

Riddle, R. L., \& Levin, M. J. (2017). Anthropogenic soil criteria, identification and classification of human-altered and human-transported materials. In M. J. Levin, K.-H. J. Kim, J.-L. Morel, W. Burghardt, P. Charzynski, R. K. Shaw, \& IUSS Working Group SUITMA (Eds.), Soils within cities. Global approaches to their sustainable management-Composition, properties, and functions of soils of the urban environment. Stuttgart: Schweizerbart.

Robert, S. (2012). Soil quality assessment for spatial planning in urban and peri-urban areas. The Provence coal field case study. Marseille: Faculté des sciences de Luminy.

Sanderson, E. W. (2009). Mannahatta: A natural history of New York City. New York, NY: Abrams.

Schaetzl, R. J., \& Thompson, M. L. (2015). Soils: Genesis and geomorphology (2nd ed.). Cambridge: Cambridge University Press.

Schneider, J. (2000). Concept soil map. Small investigation-A lot of information. In W. Burghardt \& C. Dornauf (Eds.), Proceedings of the First International Conference on Soils of Urban, Industrial, Traffic and Mining Areas (Vol. I, pp. 137-140). Essen: University of Essen.

Secchi, B. (1986). Progetto di suolo [The project for the ground]. Casabella, 520, 19-23.

Secchi, B., Viganò, P., \& Fabian, L. (2016). Water and asphalte. The project of isotropy. Zurich: Park Books.

Spirn, A. W. (1984). The granite garden: Urban nature and human design. New York, NY: Basic Books.

Swiss Spatial Planning Act. (2019). Retrieved from https://www.admin.ch/opc/en/classifiedcompilation/19790171/index.html\#fn1

Van De Vijver, E., Delbecque, N., Verdoodt, A., \& Seuntjens, P. (2020). Estimating the urban soil information gap using exhaustive land cover data: The example of Flanders, Belgium. Geoderma, 372, 114371. https://doi.org/10.1016/j.geoderma.2020.114371

Vialle, A., \& Verrecchia, E. P. (2018). Du sol comme œuvre, au sol comme archive de l'action humaine: Microhistoire d'un principe d'espérance à travers deux textes du pédologue Dan H. Yaalon [From soil as a hu- 
man work, to soil as human archive: Microhistory of a principle of hope through two texts by pedologist Dan H. Yaalon]. In P. Mantziaras \& P. Viganò (Eds.), Urbanisme de l'espoir. Projeter des horizons d'attente [Urbanism of hope: Projecting horizons of expectation]. Geneva: Metis Presses.

Viganò, P., Barcelloni Corte, M., \& Vialle, A. (in press). Le sol de la ville-territoire: Projet et production de connaissances [The soil of the city-territory: Project and knowledge production]. Revue d'Anthropologie des Connaissances.

Yaalon, D. H., \& de Richter, D. (2011). "The changing model of soil" revisited. Soil Science Society of America Journal, 76, 766-778.

Yaalon, D. H., \& Yaron, B. (1966). Framework for manmade soil changes-An outline of metapedogenesis. Soil Science Society of America Journal, 102, 272-278.

\section{About the Authors}

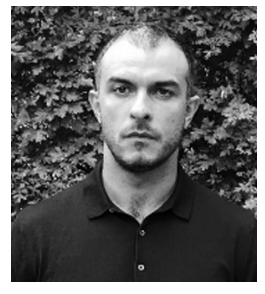

Antoine Vialle is Architect (2007) and Former Fellow of the French Academy in Rome-Villa Medici (2010-2011). He has been Scientific Assistant and Lecturer in various schools since 2011 and is currently developing a PhD on the soils of the Swiss city-territory at the EPFL Laboratory of Urbanism with Profs. Paola Viganò (EPFL Lab U) and Éric Verrecchia (UNIL IDYST). In 2019, he was Doctoral Visiting Student at the MIT Leventhal Center for Advanced Urbanism.

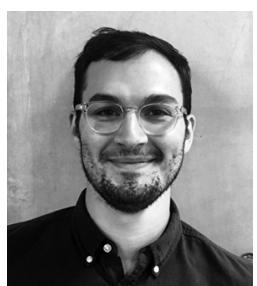

Mario Giampieri is an Urban Planner and Spatial Analyst. He has lectured at Fordham University and MIT and has co-taught courses using advanced spatial analysis to understand regional urban systems at the Universidad de Ingeniería y Tecnología (Lima) and the Wildlife Conservation Society (New York). He is an Urban Planner at WXY and a Research Affiliate of the MIT Leventhal Center for Advanced Urbanism. 